DOI: http://dx.doi.org/10.9771/rcufba.v15i0.45867

\title{
RESENHA DO LIVRO: \\ Teoria da contabilidade financeira: fundamentos e aplicações / organização Eduardo Flores, Guillermo Braunbeck, Nelson Carvalho. São Paulo: Atlas, 2018.
}

\author{
Silvana Dalmutt Kruger \\ Universidade Comunitária da Região de Chapecó - Unochapecó \\ silvanak@unochapeco.edu.br
}

Reconhecer que toda prática pode ser fundamentada sob o embasamento de uma teoria, e que toda teoria pode orientar melhores práticas, é uma justificativa para o estudo e compreensão das abordagens dos aspectos teóricos da contabilidade. A medida que a utilização da contabilidade fundamenta-se no estudo das variações do patrimônio, os diversos usuários demandam por distintas informações da contabilidade, quer para o controle, planejamento, gestão administrativa, contábil, tributária, decisória, etc. Neste sentido, compreender os aspectos teóricos que sustentam as práticas contábeis, torna-se diferencial competitivo para as organizações, mas também diferencial para a atuação dos profissionais da contabilidade.

A obra "Teoria da Contabilidade Financeira", organizada por Eduardo Flores, Guillermo Braunbeck e Nelson Carvalho, com participação de outros dezoito colaboradores (alunos de pós-graduação do Departamento de Contabilidade da FEA-USP), propõe reflexões acerca das abordagens que sustentam a teoria da contabilidade, questionando os aspectos do embasamento da teoria e das técnicas contábeis. A obra permite discutir e ampliar as percepções da abrangência da importância da contabilidade como linguagem aos negócios, bem como, oferece densidade teórico-conceitual e questões para reflexão e de múltipla escolha, tornando o material rico e diferenciado para o ensino da contabilidade.

Ao apresentar o prefácio, Alexsandro Broedel Lopes, indica que a obra possui dois objetivos principais: (i) "busca oferecer uma visão estruturada dos fundamentos sobre os quais a contabilidade financeira se apoia, a partir de uma reflexão centrada na utilidade dessa área do conhecimento para aqueles que dela fazem uso ou extraem algum benefício." E (ii) "busca abordar de maneira crítica e contemporânea as fronteiras, desafios, limitações e oportunidades que fazem parte da trajetória de desenvolvimento da teoria da contabilidade financeira." Ainda, ao apresentar o prefácio, evidencia-se o propósito de oferecer "uma contribuição efetiva para a prática contábil ao provocar a reflexão fundamentada sobre o fenômeno contábil e seus motivadores, reflexão essa que é essencial para o exercício dos julgamentos necessários à prática profissional nos dias atuais."

Contemplando discussões conceituais, a evolução das abordagens da contabilidade, tanto sob os aspectos teóricos, quanto práticos, o livro está organizado em 7 capítulos. Particularmente eu destacaria este livro com duas ênfases: (i) primeiramente os aspectos 
reflexivos da teoria da contabilidade (ponderando conceito, finalidade, utilização, etc.), mas sem pretensão de findar as discussões, os autores são sinceros em expor as dificuldades e por vezes até mesmo a falta de consenso sobre a teoria da contabilidade, e que está se embasa nas práticas e ações humanas, logo é influenciada e constantemente modificada. (ii) A segunda ênfase se refere às abordagens conceituais e normativas, permitindo a compreensão da abrangência e importância da contabilidade para o processo de tomada de decisão, constantemente os autores resgatam a importância das informações para os distintos usuários da contabilidade.

No decorrer de cada capítulo, é possível observar aspectos evolutivos da utilização da contabilidade, bem como identificar os elementos teóricos que sustentam as práticas contábeis. No capítulo 1, abordam os fundamentos da teoria contábil, refletindo sobre sua importância, objetivo, fundamentação e essência. Os autores agregam reflexões sobre a teoria da contabilidade (e mesmo que indiquem a não pretensão de concluir ou finalizar os conceitos), instigam a percepção acerca da abrangência da contabilidade. A contabilidade é destacada como mecanismo informacional para a explicação e predição de fenômenos econômicos, aos quais as entidades estão expostas no contexto de suas atividades.

O capítulo 2 discute as características, utilidade e objetivo da contabilidade. Os autores evidenciam a evolução contábil a partir dos diversos usuários, bem como das necessidades e mudanças da sociedade. Apresentam como fatores que interagem e refletem nos processos contábeis: (i) o arcabouço legal; (ii) a regulamentação e; (iii) as fontes de recursos financeiros; os quais potencializam a utilidade e relevância do uso da contabilidade pelas entidades. Independente da concepção da contabilidade ser técnica ou ciência, a geração de informações (para os diversos e distintos usuários), torna-se o principal objetivo, com a finalidade de auxiliar o processo de tomada de decisão destes usuários.

No capítulo 3, os autores remetem ao questionamento do que é a teoria da contabilidade, apresentando as distinções entre a teoria normativa e a teoria positiva, bem como das dificuldades do consenso acerca dos enfoques pelos pensadores e pesquisadores. O contexto social e as ações humanas, bem como os ambientes distintos: econômico, social e patrimonial, inibem a definição de uma teoria geral da contabilidade. Indicam a teoria da contabilidade financeira ("focada no comportamento e nas necessidades das pessoas no que diz respeito à informação contábil financeira", p. 53), e como teorias alternativas consideram: teoria institucional, da legitimidade, comunicação e semiótica, contingencial, comportamental. Neste capítulo os autores contemplam estudo de caso comparativo entre os aspectos normativos e positivistas da contabilidade.

O capítulo 4, intitulado "teoria da contabilidade financeira e estruturas conceituais", apresentam-se documentos e a trajetória dos princípios contábeis, bem como das estruturas conceituais que subsidiam o processo de mensuração, registro e evidenciação das informações contábeis. Pode-se observar aspectos históricos relacionados à evolução das características qualitativas da contabilidade. Esclarecem a distinção e o impacto dos sistemas jurídicos (common law e o code law/ou civil law), na forma de conceber as práticas contábeis. E na abordagem da estrutura conceitual, contemplam a importância da harmonização contábil, ponderam como contrassenso os ordenamentos baseados em regras, que tratam de forma única entidades desiguais.

O capítulo 5, aborda o ativo e sua mensuração. Inicialmente indicam a importância da definição do que é ativo, as características de (i) geração de benefício futuro; (ii) controlado pela entidade; (iii) resultados de eventos passados, ou conceitualmente apresentam o ativo como "um instrumento com potencial de gerar benefícios econômicos, que está à disposição da entidade, para atingir os seus objetivos com um custo de oportunidade melhor do que para terceiros" (p. 113). No decorrer do capítulo, indicam as bases de mensuração dos ativos e as categorias mais relevantes, o valor justo e o valor presente são contemplados como critérios de 
mensuração dos ativos. De acordo com as características dos ativos indicam a composição dos itens de ativos, conforme a estrutura do balanço patrimonial.

Já no capítulo 6, intitulado "passivo, patrimônio líquido e conservadorismo", contemplam as características dos recursos do capital próprio ou de terceiros. O passivo é "uma obrigação presente da entidade, derivada de eventos passados, cuja liquidação se espera que resulte na saída de recursos da entidade capazes de gerar benefícios econômicos." (p. 146). E o patrimônio líquido é conceituado como "o interesse residual nos ativos da entidade depois de deduzidos todos os seus passivos (abordagem da teoria do proprietário)" (p.146). Os autores evidenciam a importância do conservadorismo aos profissionais da contabilidade (significa ser prudente).

Por fim, último capítulo do livro é intitulado como "Receitas, Despesas, Ganhos, Perdas e Lucros". Os autores distinguem os termos receitas e despesas versus ganhos e perdas, considerando a natureza temporal distinta das contas de resultado. Indicam que as receitas e despesas são decorrentes das atividades rotineiras, enquanto ganhos e perdas são decorrentes de eventos esporádicos ou sazonais. Os autores questionam o seria lucro e como mensurá-lo, sobre a distinção entre lucro econômico e lucro contábil, bem como a diferença de mensuração entre eles. Destacam a importância das contas de resultado, pelo impacto direto delas no patrimônio líquido e no balanço patrimonial.

Os autores agregam a visão crítica dos conceitos e não se preocupam em delimitá-los, deixam evidências que a contabilidade é influenciada pelas ações humanas e como tal, está em constante evolução. A obra pode ser utilizada como material de apoio das disciplinas de teoria de contabilidade e de forma complementar em diversos componentes curriculares, como suporte a contabilidade societária, por exemplo, tendo em vista o conjunto de questões de múltipla escolha, questões reflexivas e os estudos de casos. Ainda, torna-se um exemplo material para revisão de conceitos para auxiliar os estudantes em exames (exame de suficiência, prova do Enade, concursos públicos, etc.). Mas não somente para a graduação, a obra é rica em reflexões e não se prende ao passado, permite a percepção de diversas inquietações acerca das abordagens da teoria da contabilidade, o que amplia sua utilização pelos docentes e estudantes, inclusive ao nível de pós-graduação.

Outro diferencial desta obra, está no aspecto não delimitado dos conceitos, na forma de evidenciação de fontes e especialmente nas discussões que enaltecem os aspectos da evolução conceitual contábil, o que de fato é um presente para professores e estudantes da contabilidade. Mas é cabível destacar que não é uma obra de conceitos prontos, mas sim para a formação do senso crítico e reflexivo sobre a abrangência da teoria contábil.

Aos docentes, a obra é um presente, tendo em vista a possibilidade além do conteúdo, da utilização das questões reflexivas, de múltipla escolha e dos estudos de casos, como suporte nas atividades de sala de aula, tendo em vista que o livro oferece aos docentes material suplementar gratuito, com questões e respostas sugeridas pelos autores.

Recomendo a leitura, não somente aos acadêmicos e docentes de teoria da contabilidade, mas também aos egressos da contabilidade e profissionais do mercado, como fonte de atualização e reflexão acerca dos aspectos teóricos e conceituais que sustentam às práticas contábeis. 